\title{
Uji Kerawanan Terhadap Tsunami Dengan Sistem Informasi Geografis (SIG) Di Pesisir Kecamatan Kretek, Kabupaten Bantul, Yogyakarta
}

\author{
Petrus Subardjo dan Raden Ario* \\ Jurusan IImu Kelautan, Fakultas Perikanan dan Ilmu Kelautan, Universitas Diponegoro \\ JI. Prof. Soedarto, SH. Kampus UNDIP Tembalang, Semarang 50275 \\ Email: ario_1960@yahoo.com
}

\begin{abstract}
Abstrak
Tsunami merupakan jenis bahaya alam yang belum dapat diprediksi waktu terjadinya. Tsunami adalah salah satu bencana alam yang senantiasa mengancam penduduk yang tinggal di daerah pesisir. Walaupun jarang terjadi, namun daya hancurnya yang besar membuat bencana tsunami ini harus diperhitungkan. Kabupaten Bantul, Yogyakarta termasuk salah satu wilayah rawan bencana tsunami yang meliputi 21 wilayah di Indonesia.Untuk mendukung langkah-langkah mitigasi bencana terhadap tsunami, salah satunya dengan memetakan tingkat kerentanan bencana tsunami di pesisir Pantai Depok Kecamatan Kretek, Kabupaten Bantul, Yogyakarta. Penelitian dilaksanakan pada bulan Oktober sampai dengan Desember 2012. Adapun lokasi secara administratif masuk wilayah Desa Parangtritis, Kecamatan Kretek, Kabupaten Bantul, Yogyakarta. Penelitian ini bertujuan untuk menyusun peta kerentanan wilayah terhadap tsunami di pesisir Pantai Depok Kecamatan Kretek,Bantul, Yogyakarta. Metode analisis yang dilakukan pada beberapa macam peta dikenal dengan metode tumpang susun (overlay method). Hasil penelitian menunjukan bahwa lokasi Ketinggian daratan di Kecamatan Kretek terdiri dari daerahdaerah yang rendah di wilayah pesisir hingga daerah tinggi di sekitar pegunungan. Dataran rendah yang berada di dekat pantai mempunyai tingkat kerawanan paling tinggi terhadap bencana tsunami dibandingkan dengan dataran yang tinggi. Ketinggian ini akan berpengaruh pada daerah penggenangan tsunami (Tsunami Inundation Area). Wilayah yang sangat rendah di Kecamatan Kretek terdapat hampir di seluruh kecamatan yang berada di pesisir. Secara umum beberapa bagian wilayah pesisir yang rendah ini akan sangat mungkin terendam apabila di kemudian hari terjadi lagi bencana tsunami dengan tinggi run up yang sama
\end{abstract}

Kata Kunci: Kerawanan, Tsunami, Pesisir, Bantul

\section{PENDAHULUAN}

Tsunami adalah salah satu bencana alam yang senantiasa mengancam penduduk yang tinggal di daerah pesisir. Walaupun jarang terjadi, namun daya hancurnya yang besar membuat bencana tsunami ini harus diperhitungkan. Di Indonesia, menurut Pusat Vulkanologi dan Mitigasi Bencana Alam, wilayah rawan bencana tsunami meliputi 21 wilayah, yaitu: Nanggroe Aceh Darussalam, Sumatera Utara, Sumatera Barat, Bengkulu, Lampung-Banten, Jawa Tengah Bagian Selatan, Jawa Timur Bagian Selatan, Bali,
Nusa Tenggara Barat, Nusa Tenggara Timur, Sulawesi Utara, Sulawesi Tengah, Sulawesi Selatan, Maluku Utara, Maluku Selatan, Biak-Yapen, Balikpapan, Sekurau, Palu, Talaud, dan Kendari (Putranto, 2006).

Gempa tektonik berkekuatan Mw 7,7 telah terjadi pada tanggal 17 Juli 2006 (USGS, 2006)yang berpusat di selatan Jawa Barat pada kedalaman $10 \mathrm{~km}$ di bawah dasar laut. Gempa ini telah mengakibatkan tsunami setinggi 3,4 meter. Gelombang tsunami yang melanda kawasan Pantai Pangandaran telah merenggut korban sedikitnya ratusan jiwa, bahkan besarnya kekuatan gempa 
tersebut mengakibatkan tsunami yang melanda sepanjang pesisir selatan Jawa Barat hingga Yogyakarta dan sekitarnya (G.Suantika, drr, 2006).

Bencana menurut UNDP (1992:12) adalah suatu gangguan serius terhadap masyarakat sehingga menyebabkan kerugian yang meluas pada kehidupan manusia dari segi materi, ekonomi, dan lingkungannya.Kata tsunami berasal dari bahasa Jepang, "tsu" berarti pelabuhan, dan "nami" berarti gelombang. Gerakan vertikal pada kerak bumi dapat mengakibatkan dasar laut naik atau turun secara tiba-tiba. Mengakibatkan gangguan keseimbangan air yang berada di atasnya. Hal ini mengakibatkan terjadinya aliran energi air laut, yang ketika sampai di pantai menjadi gelombang besar yang mengakibatkan terjadinya tsunami (Pacific Tsunami Museum, 2007).

Bencana tsunami dapat menimbulkan kerugian, baik harta benda maupun jiwa. Proses rehabilitasi dan rekonstruksi akibat bencana tsunami membutuhkan waktu yang lama. Demikian juga dengan kehilangan nyawa akibat bencana tsunami merupakan hal yang perlu diperhatikan. Bencana tsunami tidak dapat dihindari tetapi akibat yang ditimbulkan oleh tsunami dapat diminimalkan dengan melakukan tindakan pencegahan. Salah satu cara yang dapat dilakukan adalah dengan mengetahui risiko suatu daerah terhadap bencana tsunami sehingga dapat dilakukan mitigasi untuk meminimalisir korban jiwa akibat bencana tsunami. Oleh karena itu perlu diidentifikasi daerah-daerah yang rentan terhadap bahaya tsunami sebagai langkah awal mitigasi bencana tsunami di masa yang akan datang.

Kawasan pantai selatan Yogyakarta secara tektonik merupakan salah satu daerah dengan tingkat seismisitas tinggi dan aktif. Aktivitas seismisitas di kawasan ini dapat menimbulkan gempa bumi dan potensi tsunami, yang dapat berkembang menjadi bencana alam. Disamping itu perairan pantai selatan Yogyakarta termasuk wilayah pesisir pantai selatan Jawa merupakan perairan terbuka lopen sea) dengan pantainya berhadapan langsung dengan Samudra Hindia.Oleh sebab itu wilayah Pesisir Pantai Depok, Kecamatan Kretek, Bantul, Yogyakarta juga relatif rawan terhadap bencana alam lainnya seperti abrasi, longsoran dan gerakan tanah. Tsunami merupakan jenis bahaya alam yang belum dapat diprediksi waktu terjadinya. Sebelum tsunami terjadi lagi di masa mendatang, yang dapat dilakukan adalah mengurangi atau meminimalkan dampak yang ditimbulkan tsunami melalui mitigasi. Untuk mendukung langkah-langkah mitigasi bencana terhadap tsunami, salah satunya dengan memetakan tingkat kerentanan bencana tsunami di pesisir Pantai Depok Kecamatan Kretek, Bantul, Yogyakarta berupa peta kerentanan wilayah terhadap tsunami yang dapat menjadi masukan data dalam upaya mitigasi penyusunan Rencana Tata Ruang Wilayah (RTRW) selanjutnya yang berbasiskan tingkat resiko tsunami, sehingga dapat meminimalisasi korban yang diakibatkan oleh bencana tsunami.

\section{MATERI DAN METODE}

Pengolahan data dalam penelitian ini dilakukan dengan bantuan komputer dan perangkat lunak (software). Pengolahan data untuk menyusun daerah rawan bencana tsunami terdiri dari beberapa tahap. Secara garis besar, langkah-langkah yang digunakan dalam penelitian ini meliputi tahap-tahap sebagai berikut:

1. Persiapan peta-peta dan data pendukungnya, untuk selanjutnya dilaksanakan image processing;

2. Ekstraksi data spasial dari citra satelit, peta rupabumi, DEM dan data pendukung lainnya:

3. Penentuan parameter-parameter yang mempengaruhi tingkat kerawanan bencana tsunami;

4. Analisis daerah rawan bencana tsunami berdasarkan parameterparameter yang mempengaruhi bencana tsunami; dan

5. Penentuan daerah rawan tsunami. 


\section{Peta digital dan citra satelit (image processing)}

Pengolahan data peta digital dan data citra satelit dilakukan dengan bantuan komputer dan perangkat lunak (software). Data masukkan yang diolah berupa peta digital dan data citra satelit. Citra satelit yang diperoleh merupakan citra mentah, sehingga perlu untuk dikoreksi terlebih dahulu. Koreksi yang dilakukan ada dua macam, yaitu koreksi radiometri dan koreksi geometri.

Cropping citra bertujuan untuk membatasi area penelitian (dalam hal ini Kecamatan Kretek, Kabupaten Bantul), sehingga interpretasi dapat difokuskan pada daerah yang diteliti. Proses penajaman citra (image enhancement) dilakukan untuk mempermudah dalam menginterpetasikan objek-objek yang ada di dalam citra. Penyusunan citra komposit ini dimaksudkan untuk memperoleh gambaran visual yang lebih baik, sehingga pengamatan objek dan pemilihan sampel dapat dikerjakan lebih baik, terutama untuk interpretasi penggunaan lahan.

\section{Ekstraksi data spasial}

$\begin{array}{rrr}\text { Ekstraksi dilakukan } & \text { mula-mula } \\ \text { dengan mengklasifikasikan } & \text { semua } \\ \text { keberadaan } & \text { faktor-faktor } & \text { yang }\end{array}$
mempengaruhi tsunami sebagai informasi yang akan di overlay. Informasi tersebut diperoleh dari pengolahan citra satelit, data DEM, peta rupabumi dan data pendukung lainnya dengan menggunakan bantuan software. Hasil ekstraksi tersebut dimasukkan ke basis data untuk dilakukan analisis spasial untuk menghasilkan peta tingkat kerawanan bencana tsunami di pantai selatan Kecamatan Kretek, Kabupaten Bantul.

Ekstraksi data tersebut berupa pemetaan karakteristik daerah pantai selatan Kecamatan Kretek, Kabupaten Bantul yang meliputi:

\section{Jarak dari sumber gempa}

Data posisi gempa di Samudera Hindia tanggal 17 Juli 2006 yang diperoleh dari U. S. Geological Survey
(USGS) diolah dengan bantuan software Global Mapper 8.0 untuk mendapatkan titik koordinat gempa dengan tipe shapefile (point). DEM bathimetri di wilayah Samudera Hindia diolah dengan menggunakan bantuan software ER Mapper 7.0 untuk menghasilkan tampilan dua dimensi (2D) dan tiga dimensi (3D) dari dasar perairan Samudera Hindia yang berdekatan dengan Kecamatan Kretek, Kabupaten Bantul.

Tampilan tiga dimensi (3D) akan menunjukkan letak daerah subduksi yang berupa pertemuan antara Lempeng Indo-Australia dan Lempeng Eurasia. Data posisi gempa dikombinasikan dengan tampilan tiga dimensi dari dasar perairan akan menghasilkan deliniasi daerah pusat gempa laut menggunakan bantuan software ArcGIS 9.2. Informasi berupa jarak dari pantai terhadap sumber gempa laut diperoleh dengan bantuan software ArcGIS 9.2. Informasi tersebut kemudian dilakukan reklasifikasi untuk menghasilkan kelas jarak dari pantai terhadap sumber gempa laut.

2. Morfologi dan elevasi lereng dasar laut sekitar pantai

DEM bathimetri di wilayah Samudera Hindia diolah dengan menggunakan bantuan software ER Mapper 7.0 untuk menghasilkan tampilan dua dimensi (2D) dan tiga dimensi (3D) dari dasar perairan Samudera Hindia yang berdekatan dengan Kabupaten Bantul. Berdasarkan tampilan tiga dimensi (3D) tersebut, dapat diperoleh informasi berupa morfologi dan elevasi lereng dasar laut sekitar pantai selatan Kecamatan Kretek, Kabupaten Bantul.

3. Jarak dari garis pantai d

Citra satelit Landsat 7 ETM+ wilayah Kecamatan Kretek, Kabupaten Bantul perekaman tahun 2003/2007 dilakukan koreksi dengan bantuan software ER Mapper 7.0. 
Berdasarkan citra satelit yang telah terkoreksi dan dikombinasikan dengan peta rupabumi Kabupaten Bantul skala 1:25.000 publikasi Bakosurtanal tahun 2001, kemudian dilakukan digitasi untuk memperoleh informasi berupa morfometri pantai, panjang garis pantai.

Informasi tersebut kemudian dilakukan reklasifikasi dengan bantuan software ArcGIS 9.2 dan ArcView 3.3 untuk mendapatkan kelas jarak dari garis pantai dengan batasan wilayah Kecamatan Kretek, Kabupaten Bantul.

4. Jarak dari sungai

Peta rupabumi Kecamatan Kretek, Kabupaten Bantul yang telah terkoreksi dengan menggunakan bantuan software ArcGIS 9.2, kemudian dilakukan digitasi untuk mendapatkan informasi berupa batas administrasi, infrastruktur, jalan dan sungai. Informasi yang berupa sungai kemudian dilakukan updating dengan melakukan overlay dengan citra satelit yang telah terkoreksi untuk mendapatkan hasil yang termutakhir.

Data sungai tersebut kemudian ditumpangsusunkan dengan batas administrasi Kecamatan Kretek, Kabupaten Bantul. Software ArcGIS 9.2 digunakan untuk reklasifikasi, dengan tujuan untuk menghasilkan kelas jarak dari sungai di wilayah pantai selatan Kecamatan Kretek, Kabupaten Bantul.

5. Ketinggian, kelerengan dan keterlindungan daratan

DEM SRTM wilayah Kabupaten Bantul diolah dengan menggunakan bantuan software ER Mapper 7.0 dan ArcGIS 9.2 untuk menghasilkan tampilan dua dimensi (2D) dan tiga dimensi (3D) dari pantai selatan Kecamatan Kretek, Kabupaten Bantul. Informasi ketinggian diperoleh dengan menganalisis spasial permukaan daratan berdasarkan ketinggian. Informasi kelerengan diperoleh dengan menganalisis spasial permukaan daratan berdasarkan kelerengan. Informasi keterlindungan daratan diperoleh dengan mengkombinasikan keberadaan bukit dengan ekosistem pesisir yang diperoleh dari ekstraksi data spasial citra satelit menggunakan software ER Mapper 7.0 dan ArcGIS 9.2.

Ketiga informasi tersebut selanjutnya dilakukan reklasifikasi. Reklasifikasi bertujuan untuk mengkelaskan masing-masing parameter berdasarkan kriteria yang dibutuhkan terkait dengan tingkat kerawanan tsunami. Informasi yang diperoleh dari reklasifikasi adalah kelas ketinggian, kelas kelerengan dan kelas keterlindungan daratan.

6. Penggunaan lahan

Informasi penggunaan lahan diperoleh dari hasil digitasi dari peta rupabumi Kecamatan Kretek, Kabupaten Bantul tahun 2001 publikasi Bakosurtanal. Hasil digitasi tersebut kemudian dilanjutkan dengan updating dengan melakukan overlay dengan citra satelit Landsat 7 ETM wilayah Kecamatan Kretek, Kabupaten Bantul perekaman tahun 2003/2007 yang telah terkoreksi untuk menghasilkan informasi penggunaan lahan yang termutakhir dan lebih valid.

\section{Penentuan parameter - parameter yang berpengaruh}

Parameter yang digunakan dalam penentuan daerah rawan tsunami dengan pendekatan SIG yang telah diuraikan di atas meliputi: jarak dari sumber penyebab tsunami, morfologi dasar laut daerah pantai, elevasi lereng bawah laut, bentuk garis pantai, jarak dari sungai, keberadaan pulau penghalang, topografi daratan, elevasi daratan, keterlindungan daratan dan jarak dari garis pantai. Pada penelitian ini, sepuluh parameter tersebut tidak seluruhnya digunakan.

Penilaian secara kuantitatif terhadap 
tingkat kerawanan bencana tsunami dilakukan melalui skoring dengan faktor pembobot dari setiap parameter yang menjadi kriteria dalam penentuan daerah rawan bencana tsunami. Parameter yang dominan mempunyai faktor pembobot yang paling besar. Pemberian skor dilakukan berdasarkan tingkat pengaruh parameter tersebut terhadap potensi terbentuknya tsunami. Tujuannya adalah untuk menyusun urutan tingkat kerawanan bencana tsunami.

\section{Analisis daerah rawan bencana tsunami berdasarkan parameter - parameter yang mempengaruhi}

Dalam menunjang sistem analisis komputer, maka semua masalah harus disajikan dalam suatu bentuk model matematis agar dapat memberikan gambaran tentang sistematika yang jelas. Pemodelan matematis yang dipakai dalam pendefinisian masalah dapat dilakukan dengan model pembobotan.

Sistem pemberian bobot dan skor untuk setiap parameter dan klasifikasi dalam parameter di atas akan berbedabeda dengan tujuan:

1. Untuk menunjukkan parameterparameter yang memberikan kontribusi besar maupun kontribusi kecil dalam penentuan daerah rawan bencana tsunami

2. Untuk menunjukkan perbedaan dan kontribusi dari tiap-tiap tingkat dalam parameter yang bersangkutan.

Berdasarkan pertimbangan tersebut, maka klasifikasi dan pemberian bobot serta skor untuk parameter jarak dari sumber gempa, ketinggian daratan dan kelerengan topografi dapat dilihat masingmasing disajikan pada Tabel 1, Tabel 2 dan Tabel 3.

Untuk klasifikasi dan pemberian bobot serta skor untuk parameter jarak dari sungai, keterlindungan daratan dan keberadaan pulau penghalang dapat dilihat pada Tabel 4, Tabel 5 dan Tabel 6. Klasifikasi dan pemberian bobot serta skor untuk parameter morfologi garis pantai dan jarak dari garis pantai dapat dilihat pada Tabel 7 dan Tabel 8.

Tabel 1. Jarak Pantai Dari Sumber Gempa

\begin{tabular}{lllrr}
\hline No. & Jarak $(\mathrm{km})$ & Skor & Bobot & Total Skor \\
\hline 1. & $0-150$ & 1 & 10 & 10 \\
2. & $151-260$ & 2 & 10 & 20 \\
3. & $>260$ & 3 & 10 & 30 \\
\hline
\end{tabular}

Sumber: Diposaptono (2008)

Tabel 2. Ketinggian Daratan

\begin{tabular}{llrrr}
\hline No. & Tinggi $(\mathrm{m})$ & Skor & Bobot & Total Skor \\
\hline 1. & $0-5$ & 1 & 15 & 15 \\
2. & $6-10$ & 2 & 15 & 30 \\
3. & $11-15$ & 3 & 15 & 45 \\
4. & $16-20$ & 4 & 15 & 60 \\
5. & $>20$ & 5 & 15 & 75 \\
\hline
\end{tabular}

Sumber: Lida (1963) 
Tabel 3. Kelerengan Topografi

\begin{tabular}{lllrrc}
\hline No. & \% Lereng & Jenis Lereng & Skor & Bobot & Total Skor \\
\hline 1. & $0-2$ & Datar & 1 & 10 & 10 \\
2. & $2-6$ & Landai & 2 & 10 & 20 \\
3. & $6-13$ & Agak miring & 3 & 10 & 30 \\
4. & $13-20$ & Miring & 4 & 10 & 40 \\
5. & $20-55$ & Curam & 5 & 10 & 50 \\
6. & $>55$ & Sangat curam & 6 & 10 & 60 \\
\hline
\end{tabular}

Sumber: Van Zuidam (1983)

Tabel 4. Jarak Dari Sungai

\begin{tabular}{lllll}
\hline No. & Jarak $(\mathrm{m})$ & Skor & Bobot & Total Skor \\
\hline 1. & $0-450$ & 1 & 10 & 10 \\
2. & $451-900$ & 2 & 10 & 20 \\
3. & $901-1350$ & 3 & 10 & 30 \\
4. & $1351-1800$ & 4 & 10 & 40 \\
5. & $1801-2250$ & 5 & 10 & 50 \\
6. & $>2250$ & 6 & 10 & 60 \\
\hline
\end{tabular}

Sumber: Hajar (2006),

Tabel 5. Keterlindungan Daratan

\begin{tabular}{llrrr}
\hline No. & Keterlindungan Daratan & Skor & Bobot & Total Skor \\
\hline 1. & Terbuka/Tidak terlindung & 1 & 15 & 15 \\
2. & Terlindung & 3 & 15 & 45 \\
\hline
\end{tabular}

Sumber: Hajar (2006)

Tabel 6. Keberadaan Pulau Penghalang

\begin{tabular}{llccc}
\hline No. & $\begin{array}{l}\text { Keberadaan } \\
\text { Pulau Penghalang }\end{array}$ & Skor & Bobot & Total Skor \\
\hline 1. & Tidak ada & 1 & 10 & 10 \\
2. & Ada dengan ukuran kecil & 2 & 10 & 20 \\
3. & Ada dengan ukuran besar & 3 & 10 & 30 \\
\hline
\end{tabular}

Sumber: Hajar (2006)

Tabel 7. Morfologi Garis Pantai

\begin{tabular}{llccc}
\hline No. & Bentuk Garis Pantai & Skor & Bobot & Total Skor \\
\hline 1. & Pantai berteluk & 1 & 10 & 10 \\
2. & Pantai tidak berteluk & 2 & 10 & 20 \\
\hline
\end{tabular}

Sumber: Hajar (2006) 
Tabel 8. Jarak Dari Garis Pantai

\begin{tabular}{llccc}
\hline No. & Jarak $(\mathrm{m})$ & Skor & Bobot & Total Skor \\
\hline 1. & $<556$ & 1 & 20 & 20 \\
2. & $557-1.400$ & 2 & 20 & 40 \\
3. & $1.401-2.404$ & 3 & 20 & 60 \\
4. & $2.405-3.528$ & 4 & 20 & 80 \\
5. & $>3.528$ & 5 & 20 & 100 \\
\hline
\end{tabular}

Sumber: Bretschneider dan Wybro (1976)

Pada pemberian bobot di atas terlihat bahwa:

1. Kelas jarak dari garis pantai diindikasikan mempunyai kontribusi terbesar disusul kelas ketinggian daratan dan keterlindungan daratan (terkait dengan keberadaan ekosistem pesisir dan bukit) kemudian untuk kelas yang lain dianggap mempunyai kontribusi yang sama.

2. Skor dalam tiap-tiap kelas diberikan nilai yang berbeda dengan indikasi nilai yang kecil menunjukkan kontribusi yang besar, dan nilai yang besar menunjukkan kontribusi yang kecil.

3. Total skor merupakan hasil perkalian antara skor dan bobot dari masingmasing kelas.

Sistem pemberian bobot yang digunakan dalam penelitian ini dapat diasumsikan dan berdasarkan justifikasi ilmiah dengan melihat pada gambaran kontribusi parameter dalam penentuan daerah rawan bencana tsunami, dimana komponen yang memegang fungsi kontrol dan ketelitian data yang akurat akan diberikan bobot besar.

\section{Penentuan daerah rawan bencana tsunami}

Dalam penentuan daerah kerawanan bencana tsunami, dilakukan dengan melaksanakan metode tumpang susun (overlay method) dan permodelan data. Metode tumpang susun (overlay method) dilakukan dengan menggabungkan data grafis parameterparameter yang mempengaruhi tsunami untuk menghasilkan daerah rawan tsunami. Permodelan data dilakukan dengan tujuan sebagai perencanaan prosedur dan analisis.

\section{Metode tumpang susun (overlay method)}

Metode analisis yang dilakukan pada beberapa macam peta dikenal dengan metode tumpang susun (overlay method). Tumpang susun atau overlay suatu data grafis adalah suatu usaha untuk menggabungkan antara dua atau lebih data grafis untuk dapat diperoleh data grafis baru yang mempunyai satuan pemetaan (unit pemetaan) gabungan dari beberapa data grafis tersebut. Jadi dalam proses tumpang susun akan diperoleh satuan pemetaan baru (unit baru). Dengan kata lain, metode tumpang susun merupakan penggabungan beberapa peta tematik sehingga didapatkan peta tematik yang lain (peta tematik turunan) (Suyudi dan Diyono, 1994).

Seluruh bobot dan skor pada keseluruhan kriteria di atas akan di proses melalui software yang digunakan dan akan dihasilkan klasifikasi daerah rawan bencana tsunami berdasarkan tingkat kerawanan bencana tsunami. Banyaknya klasifikasi tingkat kerawanan tergantung oleh user. Pada penelitian ini, peneliti (sebagai user) membuat 5 (lima) klasifikasi tingkat kerawanan bencana tsunami, yaitu daerah sangat rawan, daerah rawan, daerah agak rawan, daerah aman dan daerah sangat aman dari tsunami.

Berdasarkan bobot yang diberikan untuk setiap parameter maka dapat diperoleh total skor tertinggi dan terendah. Jumlah total skor tertinggi dikurangi jumlah total skor terendah dibagi dengan jumlah kelas kerawanan maka akan diperoleh nilai rentangan skor (Rs) untuk kelas kerawanan 
atau dapat ditulis sebagai berikut:

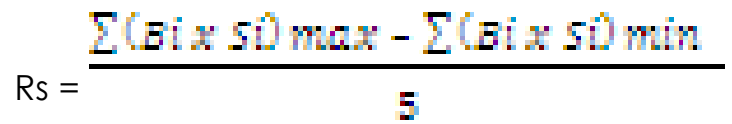

dimana:

Rs $=$ Rentangan skor

$\mathrm{Bi}=$ Bobot pada tiap kriteria

$\mathrm{Si}=$ Skor pada tiap kriteria

Dari perhitungan rumus di atas, dihasilkan nilai rentangan skor 64 dengan jumlah total skor minimum 100 dan jumlah total skor maksimum sebesar 420. Penentuan masing-masing kelas kerawanan dilakukan berdasarkan nilai rentangan skor yang ada. Untuk lebih jelas mengenai klasifikasi tingkat kerawanan tsunami, dapat dilihat pada Tabel 9. Peta tingkat kerawanan bencana tsunami untuk wilayah pantai selatan Kecamatan Kretek, Kabupaten Bantul yang dihasilkan tersebut dapat dioverlaykan dengan peta penggunaan lahan. Hasil tumpang susun

Tabel 9. Klasifikasi Tingkat Kerawanan Tsunami

\begin{tabular}{lll}
\hline No. & Kelas Kerawanan & Total Skor \\
\hline 1. & Sangat Aman $\left(\mathrm{K}_{1}\right)$ & $356-420$ \\
2. & Aman $\left(\mathrm{K}_{2}\right)$ & $291-355$ \\
3. & Agak Rawan $\left(\mathrm{K}_{3}\right)$ & $226-290$ \\
4. & Rawan $\left(\mathrm{K}_{4}\right)$ & $161-225$ \\
5. & Sangat Rawan $\left(\mathrm{K}_{5}\right)$ & $<160$ \\
\hline
\end{tabular}

tersebut dapat menjelaskan penggunaan lahan yang ada di wilayah pantai selatan Kecamatan Kretek, Kabupaten Bantul, apakah terletak di kawasan yang mempunyai tingkat kerawanan bencana tsunami tinggi atau mempunyai tingkat kerawanan rendah.

Hasil tumpang susun penggunaan lahan dengan peta tematik tingkat kerawanan bencana tsunami untuk wilayah pantai selatan Kabupaten Bantul juga dapat menjadi masukkan bagi pihakpihak yang berkepentingan, terutama Pemerintah Daerah setempat. Apabila penggunaan lahan yang berdasarkan hasil tumpang susun diketahui terletak di kawasan yang mempunyai tingkat kerawanan tinggi, maka dapat diantisipasi lebih dini terjadinya tsunami sehingga dapat meminimalisir korban jiwa dan kerugian materi.

\section{HASIL DAN PEMBAHASAN}

Berdasarkan hasil pemetaan penggunaan lahan menggunakan citra Landsat 7 ETM+, diketahui bahwa penggunaan lahan di Kecamatan Kretek terdiri dari tubuh air belukar/semak, hutan, kebun, pemukiman dan tegalan. Sebaran pemukiman di wilayah Kecamatan Kretek sebagian besar terletak di wilayah peisisir.

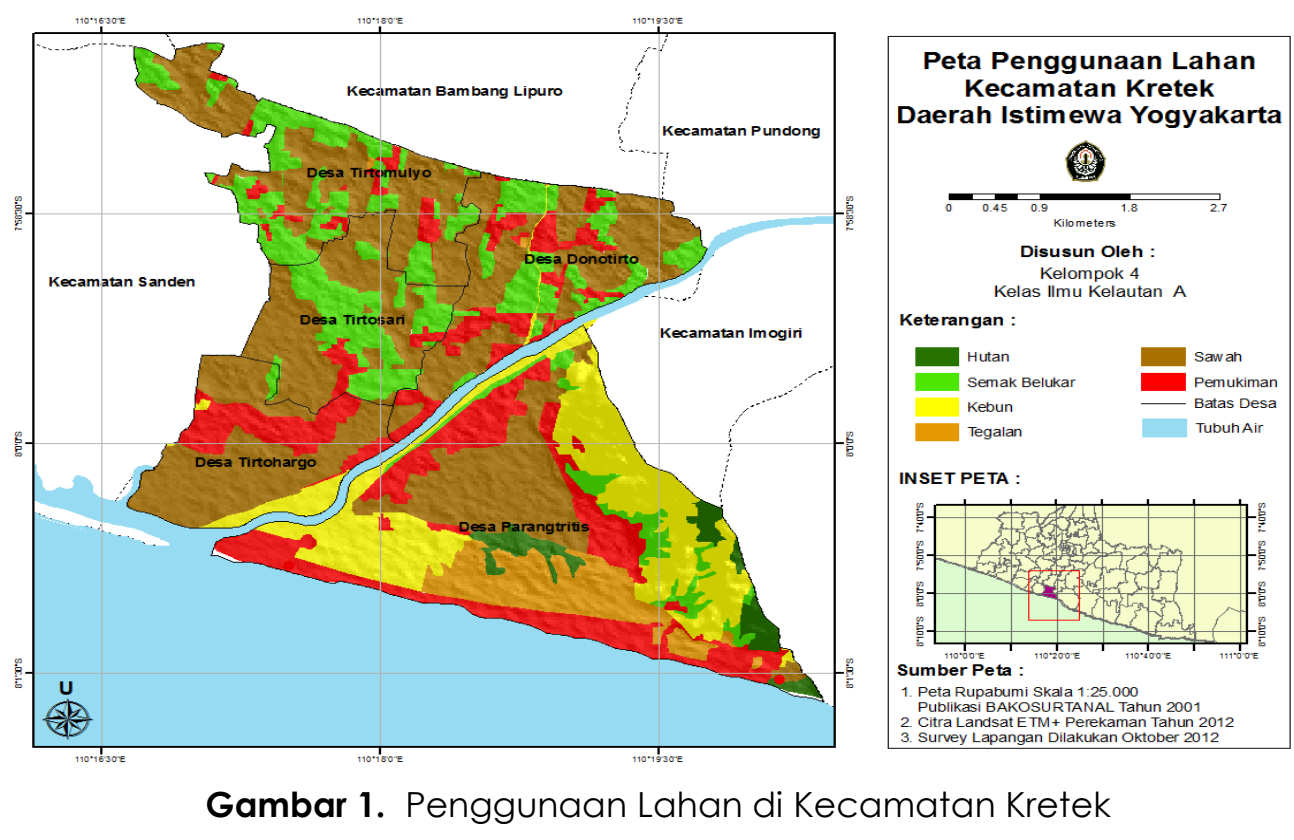




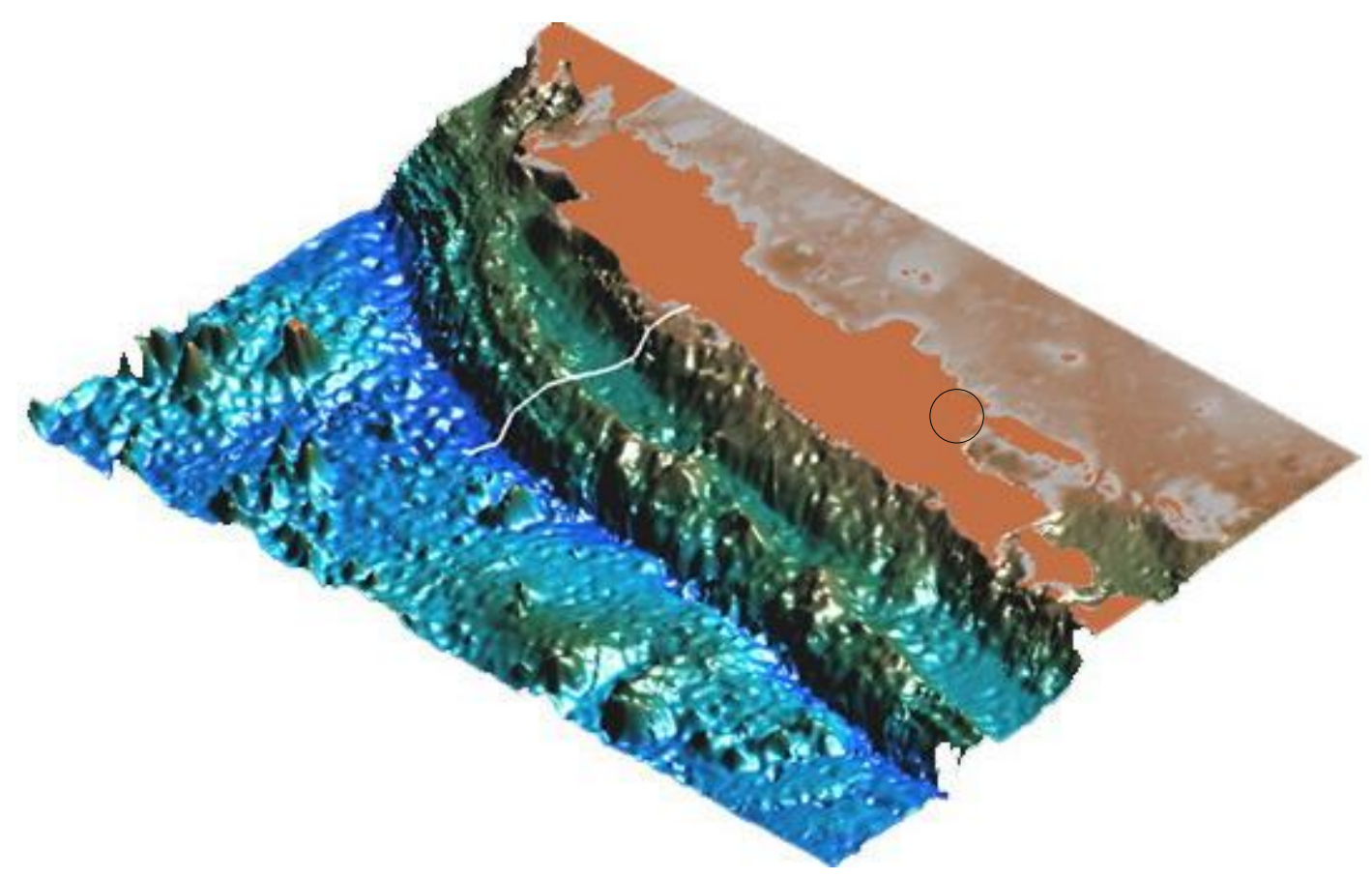

(a)

Keterangan:

: Daratan

: Laut

:Profil topografi tampak atas

: Kecamatan Kretek

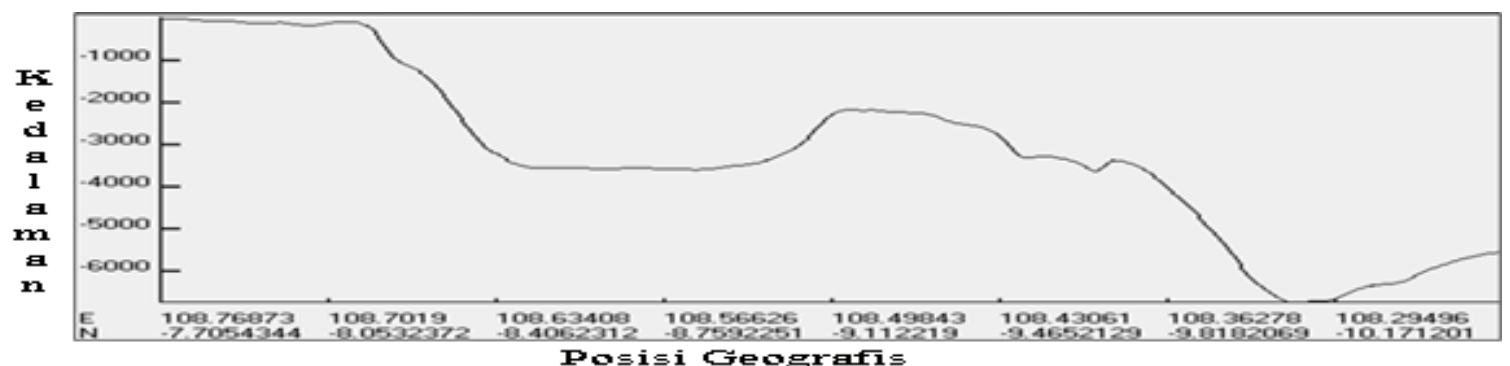

(b)

Gambar 2. (a) Pemodelan Tiga Dimensi Perairan Samudera Hindia dan (b) Profil Topografi Dasar Laut di Kab. Bantul.

Kondisi morfologi dan kelerengan dasar laut di wilayah Kecamatan Kretek relatif homogen dengan kondisi dasar yang landai, datar atau tidak bergelombang landai dan tidak berbukit. Kondisi tersebut akan memberikan fungsi penahanan yang juga relatif homogen terhadap gelombang tsunami yang menuju ke arahnya.

\section{Klasifikasi Ketinggian}

Kelas ketinggian terdiri dari lima kelas yang berdasarkan pada klasifikasi ketinggian run up tsunami oleh Lida (1963). Masing-masing kelas akan menentukan wilayah pesisir yang mungkin terkena tsunami. Wilayah dengan ketinggian rendah akan lebih rawan tsunami 


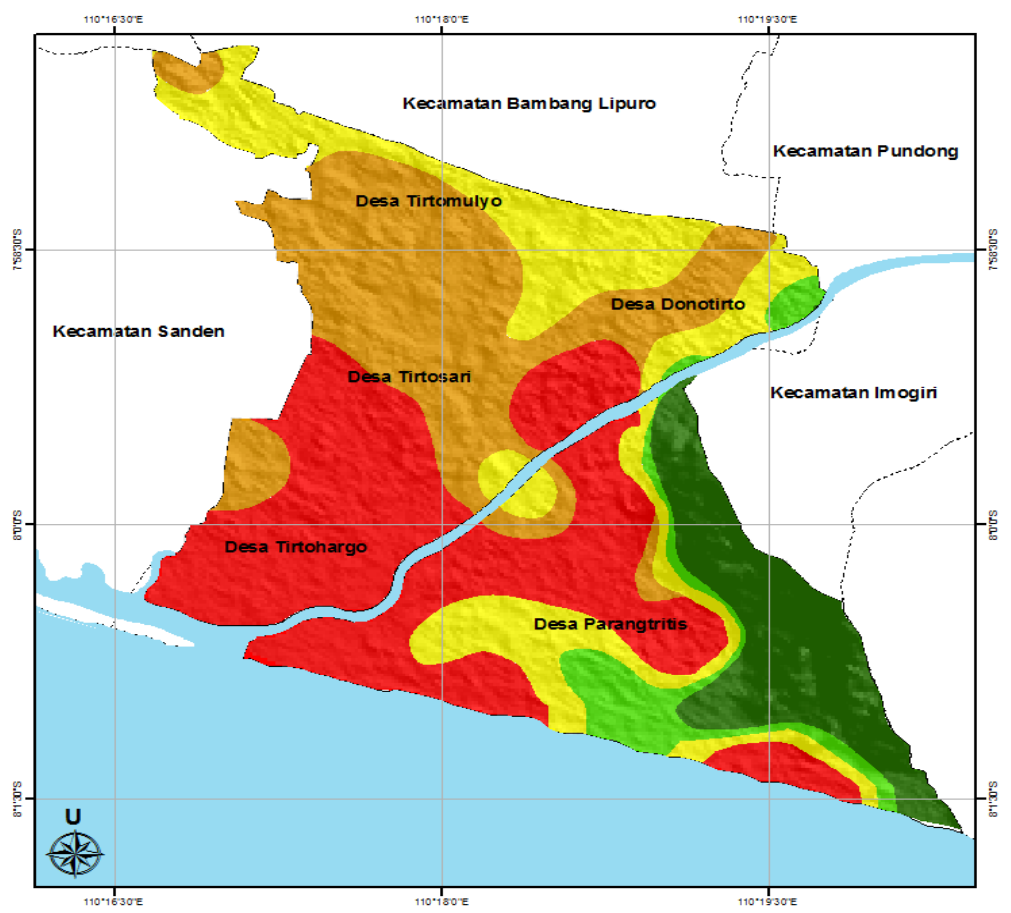

Gambar 3. Kelas Ketinggian

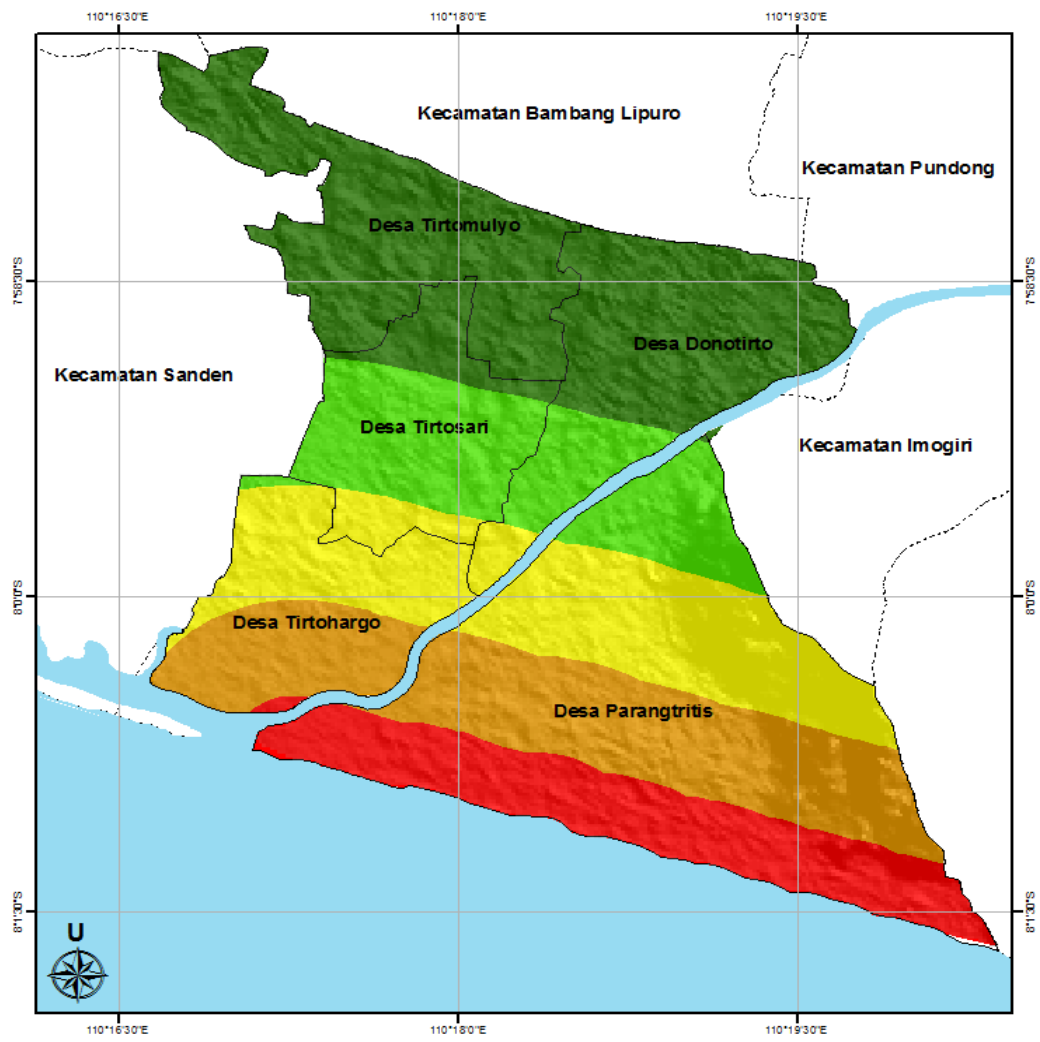

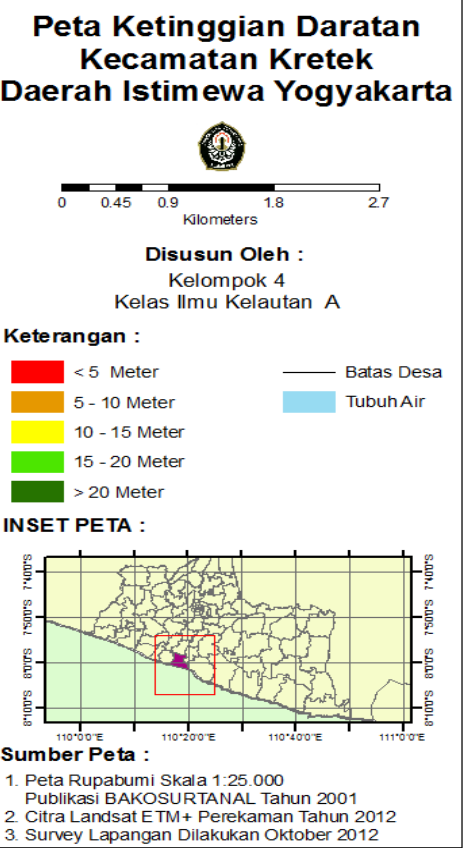

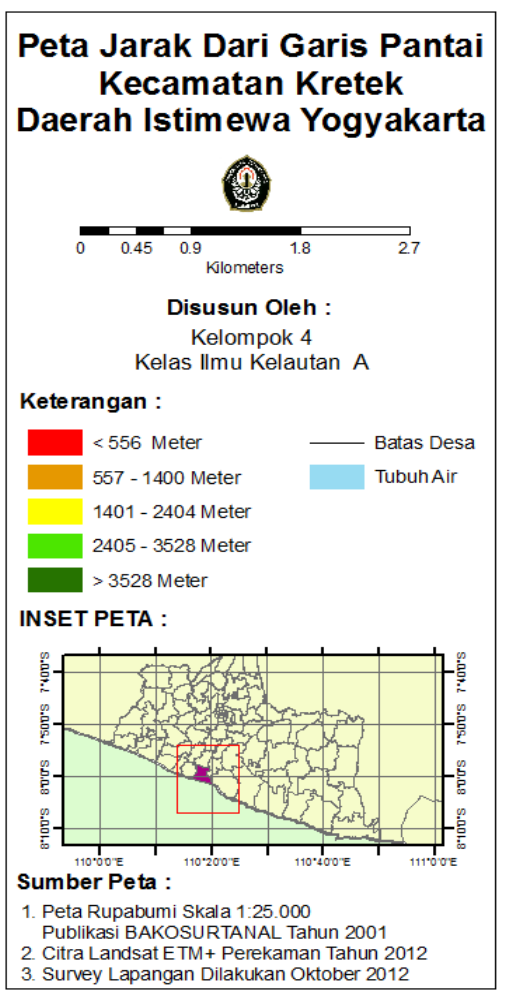

Gambar 4. Kelas Jarak dari Garis Pantai. 

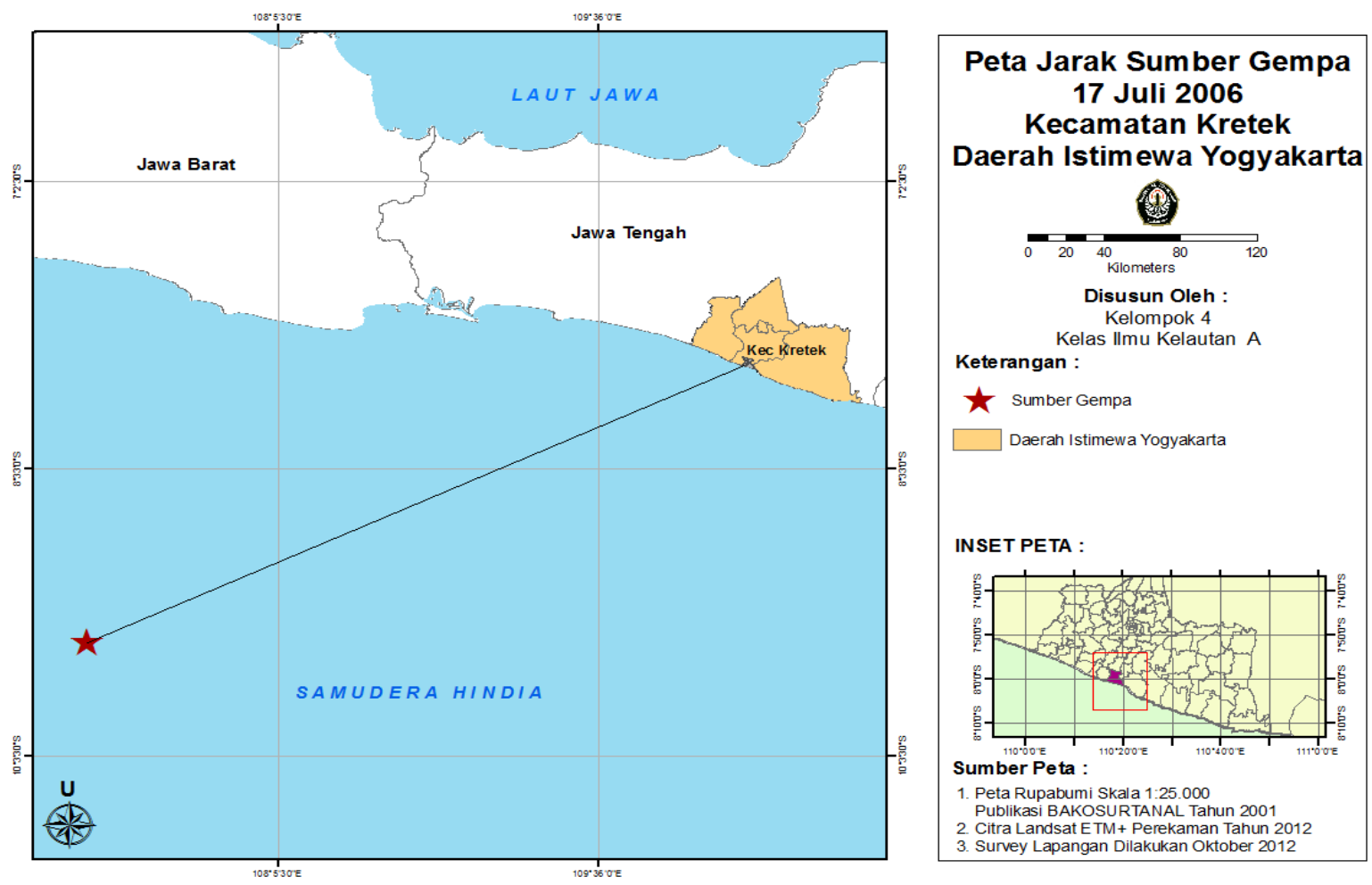

Gambar 5. Kelas Jarak Pantai dari Pusat Gempa Laut
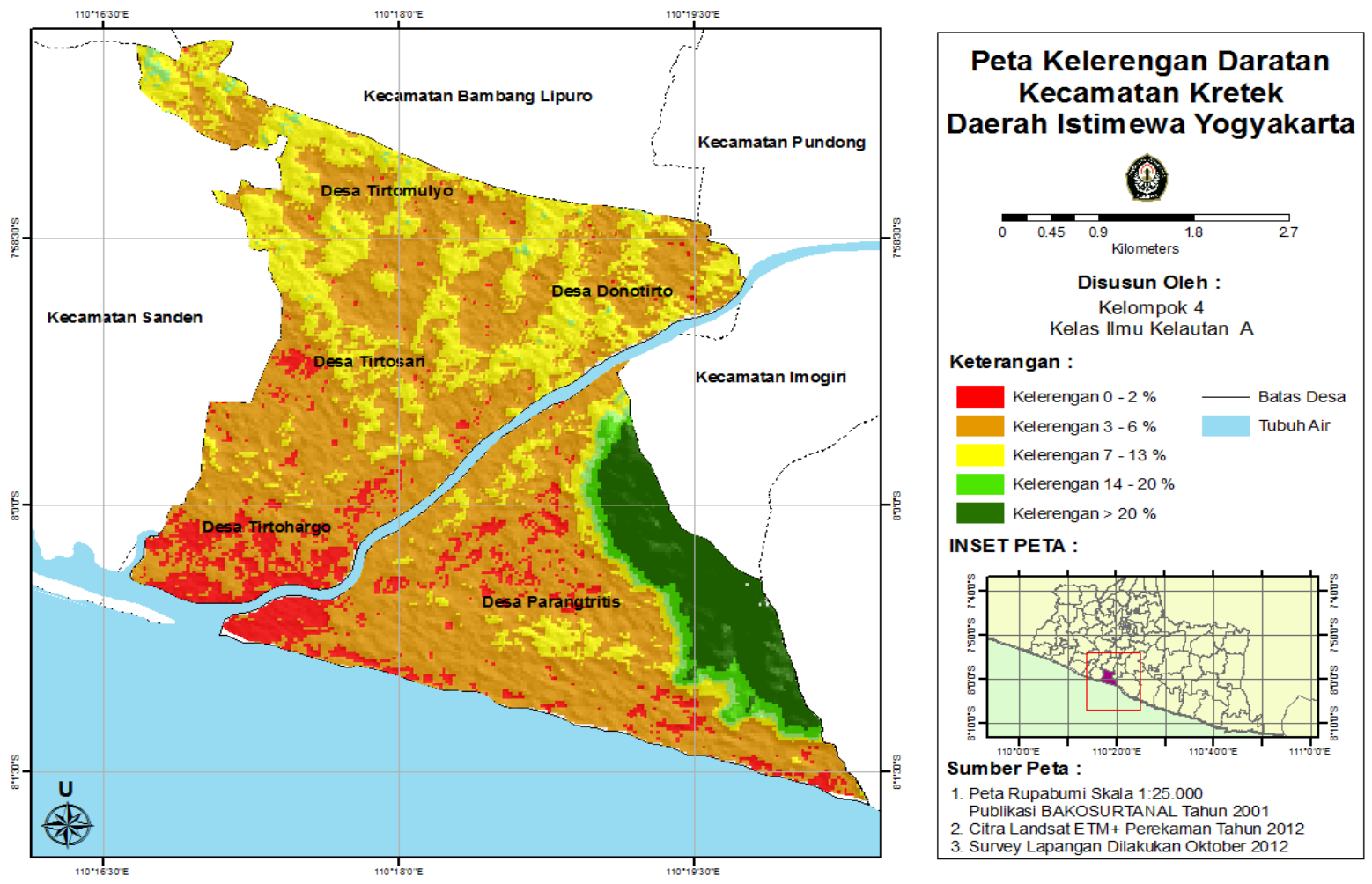

Gambar 6. Kelas Kelerengan Topografi 
dibandingkan dengan wilayah di dataran tinggi. Hampir sepanjang pantai selatan di Kecamatan Kretek memiliki ketinggian bervariasi. Dengan banyaknya sand dund yang ada di pesisir Kecamatan Kretek juga berpengaruh dalam menahan gelombang tsunami.

\section{Klasifikasi jarak dari garis pantai}

Kelas jarak dari garis pantai terdiri dari lima kelas yang berdasarkan hasil perhitungan menggunakan persamaan Bretschneider dan Wybro (1976). Berdasarkan hasil klasifikasi ini dapat diketahui jangkauan tsunami untuk masing-masing tinggi run up tsunami di pesisir Kecamatan Kretek. Daerah dengan jarak dari garis pantai kurang dari 556 meter merupakan daerah yang paling rawan tsunami, sedangkan daerah dengan jarak dari garis pantai lebih dari 3.528 meter merupakan daerah yang sangat aman dari jangkauan tsunami.

\section{Klasifikasi keterlindungan daratan}

Kelas keterlindungan daratan terdiri menjadi dua kelas, yaitu kelas terlindung dan kelas tidak terlindung/terbuka. Kelas terlindung adalah wilayah yang tidak berhadapan langsung dengan laut, karena terlindung oleh ekosistem pesisir maupun bukit. Kelas tidak terlindung/terbuka adalah wilayah yang berhadapan langsung dengan laut lepas. Keterlindungan daratan merupakan hasil overlay antara keberadaan ekosistem pesisir serta bukit, yang mempunyai fungsi sebagai pelindung apabila terjadi tsunami.

\section{Klasifikasi jarak pantai dari sumber gempa}

Peran parameter ini diketahui dengan cara mengklasifikasikan jarak daerah penelitian terhadap sumber penyebab tsunami. Untuk wilayah Kecamatan Kretek, hanya terdapat satu kelas jarak pantai dari sumber gempa. Hal ini disebabkan karena posisi lokasi penelitian yang sangat dekat dengan pertemuan lempeng. Apabila terjadi tsunami di Kecamatan Kretek, maka tsunami yang terjadi termasuk jenis near field tsunami karena mempunyai jarak tempuh kurang dari $1000 \mathrm{~km}$ dari pusat gempa di laut.

\section{Klasifikasi morfologi garis pantai}

Klasifikasi bentuk garis pantai untuk menentukan tingkat kerawanan tsunami di pantai Kecamatan Kretek termasuk dalam pantai tidak berteluk karena garis pantainya lurus

\section{Klasifikasi kelerengan topografi}

Kelas kelerengan topografi terdiri dari enam kelas berdasarkan klasifikasi kelerengan oleh Van Zuidam (1983). Sebagian besar wilayah pesisir di Kecamatan Kretek merupakan wilayah yang mempunyai kelerengan topografi kurang dari $2 \%$ atau datar dan antara 3 $6 \%$ atau landai.

\section{Klasifikasi jarak dari sungai}

Klasifikasi daerah terhadap jarak dari sungai adalah membagi daerah ke dalam kelas-kelas berdasarkan jarak dari sungai. Klasifikasi tersebut menjelaskan tingkat kerawanan bencana tsunami pada suatu daerah berdasarkan jauh dekatnya daerah tersebut dari sungai. Kelas jarak dari sungai terdiri dari enam kelas, dan masing-masing kelas mempunyai bobot dan skor yang berbeda. Banyaknya keberadaan sungai di Kecamatan Kretek mengakibatkan daerah dengan jarak kurang dari 450 meter menjadi sangat rawan tsunami, sedangkan daerah yang berjarak lebih dari 2.250 meter dari sungai menjadikan daerah tersebut aman dari tsunami. Untuk lebih jelas mengenai hasil klasifikasi jarak dari sungai (Gambar 7)

\section{Klasifikasi keberadaan pulau penghalang}

Kelas keberadaan pulau
penghalang dilihat dari keberadaannya yang dapat melindungi pulau di belakangnya dari hantaman gelombang tsunami secara langsung atau tidak. Klasifikasi ini tidak di pakai karena tidak adanya pulau penghalang di lokasi penelitian. 

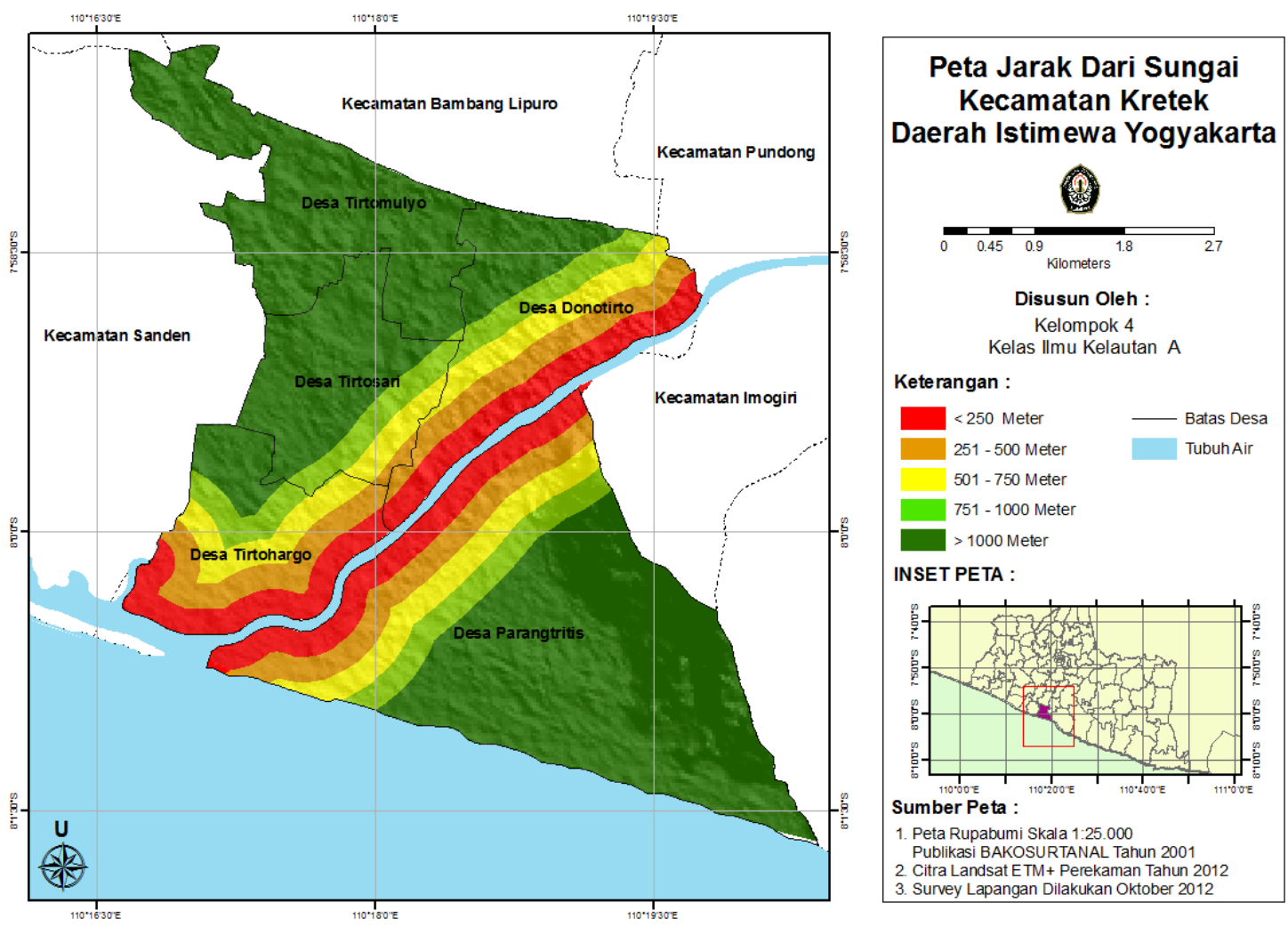

Gambar 7. Kelas Jarak dari Sungai.
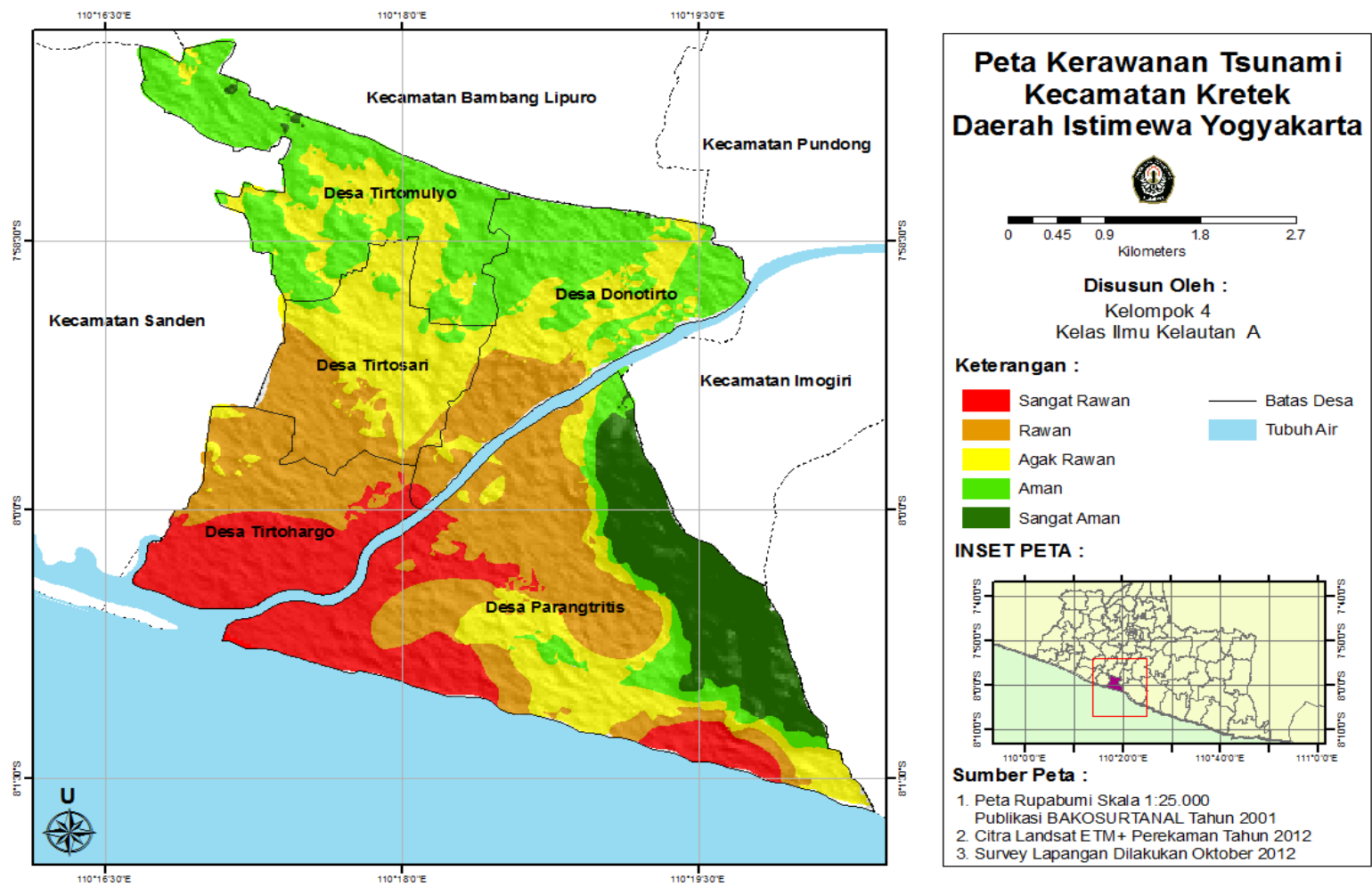

Gambar 8. Tingkat Kerawanan Bencana Tsunami di Pantai Selatan Kabupaten Bantul 


\section{Analisis daerah rawan tsunami}

Berdasarkan hasil analisis dan pemodelan SIG, diperoleh peta kerawanan bencana tsunami di pantai selatan Kecamatan Kretek yang terdiri dari lima kelas. Kelima kelas tersebut adalah kelas sangat rawan tsunami, rawan tsunami, agak rawan tsunami, aman dari tsunami dan sangat aman dari tsunami.

Kelas pertama adalah kelas sangat rawan yang ditunjukkan dengan warna merah. Kelas ini mempunyai total skor kerawanan < 160. Kisaran nilai tersebut merupakan kisaran nilai yang terkecil dibandingkan dengan kisaran nilai pada kelas-kelas yang lain. Kisaran nilai tersebut menunjukkan bahwa daerah pada kelas ini merupakan daerah paling rawan tsunami berdasarkan parameter - parameter yang digunakan.

Kelas kedua adalah kelas rawan yang ditunjukkan dengan warna oranye. Kelas ini mempunyai total skor kerawanan antara 161-225. Kelas ketiga adalah kelas agak rawan yang ditunjukkan dengan warna kuning. Kelas ini mempunyai total skor kerawanan antara 226 - 290. Kelas keempat adalah kelas aman yang ditunjukkan dengan warna hijau muda. Kelas ini mempunyai total skor kerawanan antara $291-355$.

Kelas terakhir adalah kelas sangat aman yang ditunjukkan dengan warna hijau tua. Kelas ini mempunyai total skor kerawanan antara 356 - 420. Kisaran nilai kelas ini paling besar dibandingkan dengan kisaran pada kelas lain. Hal ini menunjukkan bahwa daerah pada kelas ini mempunyai tingkat kerawanan bencana tsunami yang paling kecil. Untuk lebih jelasnya dapat di lihat pada peta kerawanan bencana tsunami (Gambar 8)

Berdasarkan peta tingkat kerawanan bencana tsunami di Kabupaten Bantul dapat dihitung luas wilayah yang masuk ke kategori sangat rawan, rawan, agak rawan, aman dan sangat aman. Luas dan persentase luas daerah dalam tingkat kerawanan bencana tsunami dapat dilihat pada Tabel 10.
Tabel 10. Luas Wilayah dalam Kerawanan Bencana Tsunami di Kabupaten Bantul

\begin{tabular}{|c|c|c|c|}
\hline $\begin{array}{l}\mathrm{N} \\
\mathrm{O}\end{array}$ & $\begin{array}{l}\text { Klasifikasi } \\
\text { Kelas }\end{array}$ & $\begin{array}{l}\text { Luas } \\
\text { (Ha) }\end{array}$ & $\begin{array}{l}\text { Persentas } \\
\text { e Luas (\%) }\end{array}$ \\
\hline 1. & $\begin{array}{l}\text { Sangat Rawan } \\
\left(K_{5}\right)\end{array}$ & 4.33573 & 19,1 \\
\hline 2. & $\begin{array}{l}\text { Rawan } \\
\left(K_{4}\right)\end{array}$ & 5811,2 & 25,6 \\
\hline 3. & $\begin{array}{l}\text { Agak Rawan } \\
\left(\mathrm{K}_{3}\right)\end{array}$ & 3115,5 & 13,9 \\
\hline 4. & $\begin{array}{l}\text { Aman } \\
\left(\mathrm{K}_{2}\right)\end{array}$ & 4630,8 & 20,4 \\
\hline 5. & $\begin{array}{l}\text { Sangat Aman } \\
\left(K_{1}\right)\end{array}$ & 4562,7 & 20,1 \\
\hline
\end{tabular}

Parameter-parameter yang berpengaruh

Analisis spasial kerawanan pantai di Kecamatan Kretek terhadap bahaya tsunami didasarkan pada faktor-faktor yang mempunyai pengaruh dalam penentuan tingkat bahaya tsunami.

Faktor-faktor di dalam penelitian ini yang mempengaruhi kerawanan tsunami adalah ketinggian daratan, jarak dari garis pantai, keterlindungan daratan, jarak pantai dari sumber gempa, morfologi garis pantai, kelerengan topografi, jarak dari sungai dan keberadaan pulau penghalang.

Parameter morfologi dasar laut dan kelerengan dasar laut mungkin dapat digunakan apabila penelitian dilaksanakan pada daerah dengan cakupan yang lebih luas, misalnya skala provinsi. Kondisi morfologi dasar laut dan kelerengan dasar laut yang beragam antar daerah yang lebih luas tersebut akan memperlihatkan tingkat kerawanan tsunami yang berbeda sehingga dapat di lakukan klasifikasi terhadap kedua parameter tersebut.

Ketinggian daratan di Kecamatan Kretek terdiri dari daerah-daerah yang rendah di wilayah pesisir hingga daerah tinggi di sekitar pegunungan. Dataran rendah yang berada di dekat pantai jelas mempunyai tingkat kerawanan paling tinggi terhadap bencana tsunami dibandingkan dengan dataran yang 
tinggi. Ketinggian ini akan berpengaruh pada daerah penggenangan tsunami (Tsunami Inundation Area). Wilayah yang sangat rendah di Kecamatan Kretek terdapat hampir di seluruh kecamatan yang berada di pesisir. Secara umum beberapa bagian wilayah pesisir yang rendah ini akan sangat mungkin terendam apabila di kemudian hari terjadi lagi bencana tsunami dengan tinggi run up yang sama

Daerah pesisir pantai selalu merupakan tempat favorit untuk dijadikan pemukiman. Mengingat daya tarik daerah pesisir, komunitas pesisir terus berkembang seiring dengan perkembangan perumahan, fasilitas maritim dan pembangunan tempat peristirahatan. Akibatnya semakin banyak penduduk dan fasilitas umum yang terancam oleh bencana tsunami.

Berdasarkan peta penggunaan lahan di Kecamatan Kretek, sebagian besar pemukiman penduduk Kecamatan Kretek terletak di wilayah pesisir. Secara empiris bahwa semakin jauh daerah dari garis pantai maka akan semakin berkurang tingkat kerawanan dari bencana tsunami. Hal ini disebabkan makin jauh lokasi dari garis pantai maka jangkauan dan run up tsunami akan semakin kecil atau berkurang.

Kecamatan Kretek mempunyai kelerengan topografi datar hingga curam. Sebagian besar wilayah pesisir di Kecamatan Kretek merupakan wilayah yang datar hingga landai. Hal ini akan mengakibatkan tingkat kerawanan bencana tsunami yang semakin tinggi. Pada pantai yang terjal, tsunami tidak akan terlalu jauh masuk ke daratan karena tertahan dan akan dipantulkan kembali oleh tebing pantai. Sedangkan di pantai yang landai, tsunami dapat menerjang dengan bebas sampai beberapa kilometer masuk ke daratan.

Keberadaan sand dune yang ada di sepanjang daerah Pantai Depok, sampai Parang Kusumo juga sangat berpengaruh sebagai penghalang tsunami sehingga runup tsunami tidak sampai ke pemukiman.

\section{KESIMPULAN}

Berdasarkan hasil penelitian dapat diambil kesimpulan bahwa tingkat kerawanan bencana tsunami di wilayah pesisir Pantai Depok Kecamatan Kretek, Kabupaten Bantul, Yogyakarta terdiri dari lima kelas, yaitu kelas sangat rawan, kelas rawan, kelas agak rawan, kelas aman dan kelas sangat aman dapat menjadi pertimbangan untuk kegiatan mitigasi bencana tsunami di Kecamatan Kretek.

\section{UCAPAN TERIMA KASIH}

Ucapan terima kasih atas bantuan dan kerja samanya kepada Galih Setyo Adiguna dkk. (Kelompok 4) Kelas A pada Program Studi IImU Kelautan FPIK UNDIP yang telah melaksanakan tugas pada Mata Kuliah SIG (Sistem Informasi Geografis).

\section{DAFTAR PUSTAKA}

Bryant, Edward. 2008. Tsunami : The Underrated Hazard (Second Edition). Praxis Publishing Ltd. Chichester. UK

Budiono, Kris. 2009. Identifikasi Longsoran Bawah Laut Berdasarkan Penafsiran

Seismik Pantul di Perairan Flores. Jurnal Geologi Indonesia, Vol. 4 No. 1

Maret 2009. Bandung, hlm. 9-17. Diposaptono, 2009. Mitigasi Bencana Tsunami. Kementerian Kelautan dan Perikanan. Jakarta.

Lida, K. 1963. Magnitude, Energy and Generation Mechanism of Tsunamis and a Catalogue of Earthquakes Associated with Tsunamis. In Tsunami Meetings $10^{\text {th }}$ Pasific Scientific Conggress. USA

Nasir, M. 1988. Metode Penelitian. Ghalia. Jakarta. $90 \mathrm{hlm}$.

Putranto, Eka T. 2006. Gempabumi dan Tsunami. Pusat Vulkanologi dan Mitigasi Bencana Alam, $5 \mathrm{hlm}$ 
Jurnal Kelautan Tropis September 2015 Vol. 18(2):82-97 $\begin{array}{cccc}\text { Van Zuidam, 1985. Aerial Photo } & \begin{array}{c}\text { Geomorphologia } \\ \text { Interpretation in Terrain Analysis and }\end{array} & \text { Maplishers. USA. } & \text { Smith }\end{array}$ 